\title{
Managerial ownership effects on cash holdings: The case of private family firms
}

\author{
Mervi Niskanen* \\ Tensie Steijvers** \\ * University of Eastern Finland \\ ** Hasselt University, Belgium
}

3.10.2011

\begin{abstract}
This paper focuses on the effect of managerial ownership on cash holdings in a sample of private family firms. Our results suggest that managerial ownership has a significant impact on cash holdings. Cash holdings are largest in the firms with no managerial ownership and lowest in the firms in which ownership and management fully coincide. However, low leverage seems to increase the need for cash holdings even in the firms in which ownership and management fully coincide. We also find weaker evidence on a nonlinear effect on cash holdings at intermediate levels of managerial stock holdings.
\end{abstract}

Key words: Cash holdings, Family Firms, Managerial Ownership

JEL: G3

Corresponding author's address: Mervi Niskanen, University of Eastern Finland, School of

Business, PL 1627, FIN-70211 Kuopio, Finland

E-mail: mervi.niskanen@uef.fi 


\section{Managerial ownership effects on cash holdings: The case of private family firms}

Private family firms can be considered to be the most common form of business organization in the world. Family-owned or controlled businesses account for over $80 \%$ of all firms and 12\% of GDP in the United States (Lee, 2006; Shanker and Astrachan, 1996). Even though there is considerable theoretical and empirical work on the capital structure of public firms and SME's (e.g. López-Gracia and Sánchez-Andújar, 2007; Hall et al., 2004; Mishra and McConaughy, 1999; Chaganti et al., 1995; Hutchinson, 1995; Titman and Wessels, 1988) there is a lack of studies that focus on the asset structure of private family firms. The aim of this paper is to fill this void by examining the effects that managerial ownership has on cash holdings in a sample of private family firms.

The theoretical finance literature offers three alternative models to explain why firms hold cash. First, the trade-off theory model claims that firms compare the marginal costs and benefits of holding cash. The second framework is provided by the pecking order theory initially outlined in Myers and Majluf (1984) and further developed by Myers (1984). This theory states that firms with information asymmetries should finance new investments first internally, then with low risk debt and finally with equity only as a last resort. This theory suggests that the role of cash is to act as a buffer between retained earnings and investments, and that firms do not have target cash levels. The fact that information asymmetries are even more pronounced for small firms, suggest that this framework has more importance for small firms than for large firms and that cash levels are lower if information asymmetries can be lowered. Third, the free-cash flow theory by Jensen (1986) claims that management has incentives to cumulate excessive amounts of cash to increase its own power and to avoid monitoring in situations when applying for new funds from the financial markets. When the firm has sufficient funds to finance its projects internally, it avoids any monitoring 
activities. This in turn may result in situations when management is free to invest in projects that suit their own interest but are not necessarily in the best interest of the shareholders.

There is a growing consensus that private family firms cannot be viewed as a homogeneous entity (Chrisman et al., 2005, Westhead and Howorth, 2007). Whether small and medium sized private family firms maintain higher cash levels, may depend on certain family firm characteristics. One such distinction can be made between different family firm types depending on the amount of shares held by the CEO i.e. managerial ownership of the firm which may influence the private family firm's cash holdings level.

When we investigate cash holdings from an agency perspective, traditional agency theory predicts that in owner-managed private family firms, the shareholder-manager agency conflict is minimal. If family firm ownership and control do not completely coincide, the shareholdermanagement agency problem arises. The contract between the family owner(s) and family manager leaves scope for management to make decisions that are not in the owners' interests. Jensen (1986) suggests that this may have implications for the level of cash holdings. Free cash flows may induce discretional behaviour by the management at the expense of the shareholders. Managers can use the funds on projects that do not benefit the shareholders or use the funds to pursue personal objectives.

The family character may also affect the shareholder-debtholder agency problem since private family firms are more vulnerable for self-control problems due to the isolation from the disciplining effect of the external capital market. Family managers want to avoid losing nonpecuniary benefits such as limiting executive management positions only to family members (Anderson and Reeb, 2003), managerial entrenchment (Gomez-Mejia et al., 2001) and 'free riding' by using the firm's resources for personal benefits and privileges of family members (Schulze et al., 2003). So, family firms might incur a higher probability of risk shifting behaviour, hold up and adverse selection in the labour market, increasing the agency costs of debt and the resulting need for higher cash holdings (Lubatkin et al., 2005; Schulze et al., 2001). However, professionalization of 
management may provide a positive signal to external parties (banks, customers etc.) Professionally managed family firms would be more flexible (Gulbrandsen, 2005). These objective, risk taking managers are less conservative and less inclined to avoid debt to realize growth which would reduce the need to hold cash.

The empirical literature on the determinants of cash holdings has recently received a lot of attention (e.g. Kim et al., 1998; Opler et al., 1999; Pinkowitz and Williamson, 2001; Faulkender, 2002; Dittmar et al., 2003; Ozkan and Ozkan, 2004; Niskanen and Niskanen, 2007; Garcia-Teruel and Martinez-Solano, 2007; Chen, 2008, Harford et al., 2008; Kuan et al., 2010). However, none of these studies focus on the effect of managerial ownership on the cash holdings of private family firms. In this paper, we examine this effect for a sample of private family firms operating in the Finnish bank-dominated capital market over the period 2000-2005. As such, this paper contributes to literature in several ways. First, we add to the literature on the determinants of cash holdings in the under-researched context of small and medium sized private family firms. In this study, we use three different definitions of a family firm. At the first stage, our first definition is based on founding family ownership, without any threshold. Our second definition is based on the family having a majority ownership. In later models, we define family firms in a strict sense as firms that are fully owned by the family. By doing this, we integrate an understanding of the internal dynamic of the family business into the corporate cash holding literature. Secondly, we take into account the heterogeneity of family firms by considering the effects of managerial ownership on the cash holdings level. Prior empirical studies (e.g. Chen, 2008; Ozkan and Ozkan, 2004; Opler et al., 1999) stress the importance of managerial ownership as a determinant of cash holdings.

This paper proceeds as follows. In the next section, the effect of managerial ownership on cash holdings in private family firms is discussed and our hypotheses are derived. In the subsequent section, the data and empirical method are discussed. Finally, we present and discuss our results. 


\section{The effect of managerial ownership on cash holdings in private family firms: hypothesis development}

The presence of market imperfections and higher agency costs of debt (Ozkan and Ozkan, 2004) seem to make cash holdings necessary for private family firms in order to avoid the high costs of acquiring new debt (transaction cost motive), to meet unanticipated contingencies that may arise and to finance investments if debt financing is unavailable or too costly (precautionary motive). Moreover, private family firms have a strong desire to keep control (Romano et al., 2000) and to pass the firm onto their heirs. Family firm owners do not want to open up equity for non family members to prevent the loss of control. Since issuing equity is no viable option for private family firms and the use of debt financing, if available, may cause financial distress and default, family firms could be less willing to apply for external debt finance. Instead, they could be more inclined to maintain higher cash balances in order to reduce the probability of financial distress and to safeguard the firm for subsequent generations (Ozkan and Ozkan, 2004). Empirically, Ozkan and Ozkan (2004) confirm that firms having families as ultimate controllers tend to hold more cash. Therefore we posit that:

H1: Family firms hold more cash than non-family firms.

Agency theory points to the conflicts of interest between managers and shareholders that may arise due to a separation of ownership and control. Taking into account the internal dynamic of family businesses, the effect of managerial ownership on corporate cash holdings in private family firms is expected to be dependent on (i) whether ownership and control of the firm is separated or not and (ii) if there is a separation between ownership and control, to what extent this separation is effectuated. 
If there is complete separation between ownership and management, which means that the family firm is managed by a non family CEO, this would reduce any privileges of owner-management, derived from parental altruism or nepotism (Gedajlovic et al., 2004). This may provide a positive signal to external parties. Nonfamily CEOs would be more qualified in terms of education and experience and could be considered as extremely valuable resources for the firm they lead such as expert advise, specialist skills and resources not in possession of a family firm ( Bennedsen et al., 2007). Similarly, Johanisson and Huse (2000) argue that professionalisation can indicate that the stakes of external stakeholders are better represented, which increases the reliability of the firm visà-vis debtholders. Contrary to family managers, non family managers can be considered as more objective and risk taking managers who follow a more growth oriented strategy (Dyer, 2006; McMahon and Stanger, 1995). Therefore, we hypothesize that:

H2a: If there is a complete separation between family firm ownership and control, the family firm is expected to maintain lower cash levels.

Alternatively, a complete separation of ownership and control would entail very significant shareholder-manager agency costs due to misalignment of incentives. Goals of manager (agent) and owner(s) (principal) can diverge because the nonfamily manager is not always familiar with the family goals or may choose other goals than those strived for by the family shareholders. By separating ownership from management by attracting professional, nonfamily managers, agency costs may arise due to information asymmetries and strains on the limits of bounded rationality among family owners (Chua et al., 2009; Gnan, 2003). The ability of the non-family, outside CEO to act in his own interests at the expense of family firms' owners will increase. Therfore, based on the free cash flow theory by Jensen (1986), it can be argued that non family CEOs have incentives to cumulate excessive amounts of cash to increase its own power and to avoid monitoring in 
situations when applying for new funds from the financial markets. When the firm has sufficient funds to finance its projects internally, it avoids any monitoring activities. This in turn may result in situations when management is free to invest in projects that suit their own interest but are not necessarily in the best interest of the shareholders. Therefore, we hypothesize, that:

$\mathrm{H} 2 \mathrm{~b}$ : If there is a complete separation between family firm ownership and control, the family firm is expected to maintain higher cash levels.

A partial separation between family firm ownership and control can lead to a conflict of interest between the family shareholders and the family CEO. It provides opportunities for owner-managers to expropriate wealth of non-managing or outside family shareholders. Managers can use the funds on projects that do not benefit the family shareholders i.e. squandering the firm's resources by consuming perquisites or making inefficient investment decisions. However, the impact of the shareholder-manager agency conflict may depend on the degree of ownership-control separation or in other words the degree of managerial ownership.

Theoretical considerations make us eager to conclude that if there is a partial separation between ownership and control, the impact of managerial ownership on cash holdings would be non-monotonic (Ozkan and Ozkan, 2004). Jensen (1986) argues that a lower level of managerial ownership could increase the shareholder-manager agency problem due to the possible misalignment of interests of the CEO with those of shareholders. Moreover, lower levels of managerial ownership are often part of the dispersed ownership structure of the firm that occurs in later generational stages. If descendants join the firm, this will increase the potential for conflicts of interest concerning business issues, diverging views and information asymmetries between owners and manager. The family starts to lose cohesiveness, has different personal goals, values, commitment to the business (Lambrecht en Lievens, 2008) and copes with a lessened intensity of 
family ties. Due to the changing nature of altruism, the descendant will put the welfare of the own nuclear household before the welfare of the extended family (Schulze et al., 2003; Lubatkin et al., 2005). This may lead to a free cash flow problem by the extraction of private benefits from the firm. They might be eager to maintain higher cash holdings to avoid any kind of monitoring from money lenders. However, other shareholders, still possessing a significant amount of the shares, given the low managerial ownership by the CEO, will avoid these high cash holdings. They may be inclined to reduce the amount of resources under control of the CEO and prefer dividend payouts. Moreover, external financiers would be more willing to lend due to the shareholders monitoring effort. Debt would even act as the ultimate tool to avoid the waste of any free cash flow on perquisites and opportunistic behaviour (Jensen, 1986; Blanco-Mazagatos et al., 2007). Consequently, we hypothesize that:

H3: If there is a partial separation between ownership and control, an increase in managerial ownership by the family manager is expected to initially decrease cash levels.

However, if managerial ownership further increases, other family shareholders will hold only a small portion of the firm's shares reducing their monitoring effort. The benefits of firm monitoring which are in proportion to their shareholding, do not outweigh their costs (Grossman and Hart, 1988). Therefore, powerful insiders being the CEO may try to exploit the firm's resources to their private benefit (Anderson and Reeb, 2004). This could lead to the entrenchment of family managers and adverse selection behaviour (Gomez-Mejia et al., 2001). For example, once a family has enough ownership for unchallenged control, it can begin to abuse its power by taking resources out of the business (Claessens et al., 2002). A major owner may use its controlling position in the firm to free ride by using the firm's resources for personal benefits and privileges of family members (Schulze et al., 2003). Moreover, parents' altruism may lead them to be generous to their children 
even when these children free ride and lack the competences to lead the firm (Anderson and Reeb, 2003). Restricting promotional opportunities and top management positions to a labour pool of family members can be problematic as the risk of hiring low quality employees increases (Lubatkin et al., 2005). Therefore, this would result in higher cash holdings to pursue private benefits. Therefore, we hypothesize that:

H4: If there is a partial separation between ownership and control, a further increase in managerial ownership by the family manager is expected to increase cash levels

If the family firm's ownership and management completely coincide, there is no shareholdermanager agency problem. Shareholder and managerial interests are completely aligned. Concentrated ownership and owner-management lead to zero level of agency costs as well as zero information asymmetries between owners and managers (Jensen and Meckling, 1976; Fama and Jensen, 1983). It can then be argued, that these firms can be expected to maintain lower cash levels. These family firms can often be considered as first generation firms which are characterized by high ownership concentration. Family bonds are strong, which improves cooperative behavior based on trust and symmetric altruism between family members (Lubatkin et al., 2005). This cooperative behavior reduces information asymmetries between family members and results in high goal congruency in order to create value for the next generations (Blanco-Mazagatos et al., 2007). Moreover, these CEOs have their wealth completely attached to the firm, which makes them long term investors with substantial wealth at risk, and want to preserve the firm in order to pass it onto the heirs. This long-term perspective can be valuable in building trust between firm and financial institution, reducing any possibility of adverse behavior by the family firm. As a consequence, the interests of creditors (e.g., banks) and family owners seem to be aligned (Steijvers and Voordeckers, 
2009). Therefore, shareholder-debtholder agency costs are expected to be low, resulting in less need to maintain cash holdings. So, we hypothesize:

H5: If ownership and control completely coincide, family firms are expected to maintain lower cash holding levels.

\section{Methodology}

\subsection{Data set}

The data for the study were collected through a private survey. The database consists of 600 Finnish SMEs and is a panel with observations from the years 2000-2005, but the number of observation varies across regression models because of missing data on some variables. Because the data is a panel, we employ appropriate panel data estimation methods in our regression models. More specifically, we employ panel estimation methods which allow for GMM to control for the possibility of an endogeneity problem: random disturbances that affect decisions about cash level may also affect firm characteristics such as leverage and growth opportunities. E.g., Garcia-Teruel and Martinez-Solana (2007) suggest this approach. More precisely, we use the GMM system estimator developed by Arellano and Bover (1995) and Blundell and Bond (1998).

\subsection{Dependent variable}


Our measure of cash holdings is the natural logarithm of the ratio cash and marketable securities to total assets. This approach has previously been adopted by, e.g., Ozkan and Ozkan (2004). Alternative approaches are the cash to sales ratio applied by, e.g., Faulkender (2002) and cash to total assets minus cash -ratio applied by Opler et al. (1999). This section discusses the motivation for the explanatory variables used in explaining the level of cash holdings

\subsection{Explanatory variables}

\section{Family ownership}

Based on previous empirical studies, e.g., Ozkan and Ozkan (2004) we expect to find that family firms overall hold more cash. In the first part of our study, we measure family ownership with a) a continuous variable measuring the share of family ownership in percentage points and b) with a dummy variable getting the value of one if the family holds more than $50 \%$ of the shares. From this database, we selected only the small and medium sized private family firms in the second part of our analysis. For these purposes, we define a family firm in a strict sense as those firms that are fully owned by the family.

\section{Managerial ownership}

Whether small and medium sized private family firms maintain higher cash levels, may depend on certain family firm characteristics such as the ownership structure of the firm or the firm's management (by a family manager versus a professional outside manager) (Westhead and Howorth, 2007). Therefore, we combine both elements into managerial ownership whereas a non family 
manager does not hold any shares of the firm since a private family firm is defined as fully owned by the family members. A family manager can own all the shares or only a partial amount of the family firm's shares.

We measure managerial ownership with several differently formulated specification of the percentage of managerial ownership. First of all, we employ a dummy variable indicating that there is no managerial ownership in place in the firm. Secondly, we employ a dummy variable indicating whether all ownership in the firm is in the hand of operating management. Finally, we take into account the possibility that the relationship between managerial ownership and cash holdings is nonlinear with the percentage of managerial ownership in its quadratic and cubic forms.

\section{Relationship lending}

The relationship lending literature essentially states that agency problems and information asymmetries between banks and borrowing firms can be alleviated through close bank-borrower relationships. This literature further concludes that small businesses in particular could benefit from a closer and more informed relationship with their banks. Among others, Binks and Ennew (1997) investigate different attributes of bank-firm relationships and suggest that small businesses could benefit from a closer and more informed relationship with their banks. Other studies show that the duration of the relationship decreases interest rates and collateral requirements (e.g., Berger and Udell, 1995). Degryse and Van Cayseele (2000) find that in Europe contract terms seem to deteriorate with the length of the bank-borrower relationship. Boot (2000) suggests that this may be caused by the fairly consolidated nature of the banking sector in Europe with fewer credit alternatives for borrowers. Previous studies on Finnish data (e.g., Niskanen and Niskanen, 2000) additionally find that while contract terms deteriorate with relationship length for larger firm, they improve with relationship length for smaller firms. More recently, Niskanen and Niskanen (2004) 
find that firms with long-term relationships and firms that have recently switched their main bank are more likely to have restrictive covenants in their loan contracts.

Ozkan and Ozkan (2004), Ferreria and Vilela (2004) as well as Garcia - Teluel and MartinezSolano (2004) all use the level of bank debt to measure the effect of relationship lending on cash holdings and conclude that high debt levels and cash holdings are positively correlated. They interpret this to imply that firms with close lending relationships hold more cash. We are able to use more detailed measures of this relationship. Our first relationship lending variable is the number of lending banks that the firm uses. Previous literature suggests that an increase in the number of lending banks reduces the closeness and value of the bank-borrower relationship. The results on this variable are not reported because they are never significant. Our second relationship lending variable is the length of the relationship that the firm has with is main bank. The central idea behind this variable is that a lot of valuable information is collected during the relationship.

\section{Firm size}

Firm size can be expected to be an important determinant of cash holdings, because information asymmetries are by nature larger in smaller firms. Additionally, it can be argued that the probability of default decreases as firm size increases. Both approaches indicate that the ratio of cash to assets should decrease as firm size increases. Alternative lines of reasoning can be based on the pecking order theory and the free cash flow theory. Opler et al. (1999) suggest that larger firms should have more cash because they are presumably more successful. Ferreira and Vilela (2004) base their arguments on the free cash flow theory and suggest that larger firms may hold more cash for two alternative reasons. One is that the number of shareholders is usually higher in larger firms, which gives rise to superior managerial discretion. Also, large firms are less likely to be takeover targets due to the large amounts of cash that they hold. In both cases, managers of large firms have more incentives to hold large cash balances than the managers of small firms. 


\section{Profitability}

Previous findings on the relationship between cash holdings and profitability are ambiguous. One line of literature suggests that more profitable firms use their profits to build up cash reserves and therefore, they can be expected to hold more cash (Opler et al. 1999; Ferreira and Vilela 2004). An alternative line of thought suggests that if cash and profits are substitutes (or if firms use profits to repay debt), there should be a negative relationship between profitability and the level of cash holdings (Kim et al. 1998).

\section{Leverage}

A number of studies imply that leverage is a significant determinant of cash holdings. Most studies suggest that the relationship between leverage and cash holdings is negative. John (1993) argues that this may be because the debt market is a substitute for holding cash. Baskin (1987) suggests that firms with high leverage ratios have a higher cost of funds and hold less cash because of the higher costs of leverage. Alternative ideas have also been suggested in the literature. E.g., Ang et al. (2000) suggest that leverage as such can reduce agency costs. This indicates that firms with low leverage have higher debt-agency costs and are therefore more likely to hold high levels of cash. Our measure of leverage is the debt-to-assets ratio of the firm. In some models we also use an alternative specification to measure leverage. That is, we use a dummy variable low leverage to indicate whether the firm's leverage is lower than the median level in the sample.

\section{Liquidity}

Investments in liquid assets can be seen as a substitute for cash. Opler et al. (1999), Ferreira and Vilela (2004) and Ozkan and Ozkan (2004) all calculate the measure for liquid assets as the ratio of working capital less cash to total assets. Because the idea behind this variable is that investments in 
liquid assets are seen as substitutes for cash holding, we expect to obtain a negative coefficient for this variable.

\section{Empirical Results}

\subsection{Descriptive statistics}

Table 1 presents descriptive statistics on key variables. The results indicate that the average ratio of cash to assets is $17.6 \%$. The results further indicate that the average level of managerial ownership in the firms is $53.88 \%$ and that $18 \%$ of the firms fall into the category in which management and ownership are fully separated while these two attributes fully coincide in $12 \%$ of the firms.

\section{TABLE 1}

Table 2 presents further descriptive statistic for subsamples with different levels of managerial ownership. Panel A Column 1 compares family firms with no managerial ownership to those with some level of managerial ownership and Column 2 compares family firms with $100 \%$ managerial ownership to those with lower levels of managerial ownership. The results in column II indicate that the level of cash to assets is lower in the firms in which CEO ownership is lower than $100 \%$ as opposed to the firms in which management and ownership fully coincide.

\section{TABLE 2}

Panel B of table two further compares subsamples with 0-5\%, 5-25\%, 25-50 and over $50 \%$ of managerial ownership. This is done to investigate if the relationship between managerial ownership and the level of cash holdings is non-linear as suggested in previous literature (e.g. Ozkan and 
Ozkan, 2004). The results in panel B support the non-linearity of the relationship suggesting that the level of cash holdings initially decreases as managerial ownership increases. The effect is then reversed at higher levels of managerial ownership but starts to decrease again as managerial ownership goes above the $50 \%$ level.

\subsection{Regression analysis}

Table 3 presents our analysis on the determinants of cash holdings in small and medium sized firms overall. The results imply that the family firms in our sample hold less cash than the non-family firms. This is the case with a continuous variable measuring family ownership as well as with a dummy variable indicating whether the family holds more than $50 \%$ of equity in the firm. This rejects hypothesis 1 and contradicts previous studies, e.g., Ozkan and Ozkan (2004). One possible reason behind the different results could be that Ozkan and Ozkan (2004) investigate the level of cash holdings in a sample of listed firms, while our sample consists of small private firms. It can be argued that the level of family ownership is lower in the listed firms as opposed to the private firms in our study and that the two studies may represent the opposite ends in a continuum in which high levels of family ownership, typical to smaller private firms, lead to lower levels of cash holdings whereas low levels of family ownership, more typical to larger listed firms, lead to higher cash holdings. Our results further indicate that while family firms overall hold less cash, the family firms in which management and ownership are fully separated hold more cash. This result is well in line with our hypothesis $2 \mathrm{~b}$, and supports the free cash flow theory of cash holdings. The results in table 3 also imply that the firms in our sample have a target level of cash holdings. The positive coefficient on the lagged cash holdings variable further implies that the firms under adjust, but that this adjustment is quite rapid. We further find that cash holdings increase with an increase in profitability and liquidity and that they decrease with an increase in firm size. 
(TABLE 3)

Table 4 presents our main analysis on the determinants of cash holdings in fully family held private firms. Our results indicate that cash holdings are likely to be higher in the firms in which there is a full separation of ownership and control, that is, when managerial ownership is $0 \%$. This contradicts hypothesis $\mathrm{H} 2 \mathrm{a}$ and supports hypothesis $\mathrm{H} 2 \mathrm{~b}$. In line with the results in table 3, this can be explained through the free cash flow theory (Jensen, 1986), suggesting that outside managers are inclined to hold high levels of cash to allow for discretionary behaviour by the management at the expense of non managing shareholders. We also find some evidence for the non-linear relationship between cash holdings and managerial ownership. Our results here imply that cash holdings decrease as managerial shareholdings increase then increase at higher levels of managerial ownership, which is in line with $\mathrm{H} 3$ and $\mathrm{H} 4$. We also run the models with a quadratic specification. The results are not statistically significant and therefore not reported here. When we investigate the interaction between low leverage and managerial ownership, we find that while overall the firms in which management and ownership are not separated hold less cash, low leverage increases the need for cash even in the firms where ownership and management fully coincide. Combined our results indicate that $100 \%$ managerial ownership leads to lower cash holdings only in the absence of low leverage. These findings support H5.

Surprisingly enough, the coefficients on the lagged cash to assets variables are nonsignificant suggesting that even if the firms in our sample overall adjust to a target level, the family firms in our sample do not seem to do so. This suggests that the family firms in our sample follow a pecking order, while the other firms do not. Our results on the other control variables are for the most part in line with our expectations. The results indicate that the level of cash holdings decreases as firm size increases. This result is in line with the idea that as information asymmetries decrease 
as firm size increases, there is less need for large cash reserves. We also find that an increase in profitability increases the level of cash holdings in our sample firms. This result is in line with, e.g., Opler et al. (1999), and Ferreira and Vilela (2004), who suggest that more profitable firms use their profits to build up cash reserves.

\section{TABLE 4}

Because of the fact that the lagged cash to assets variables in table 4 are not statistically significant, we also run the models with random effects GLS estimations. The results on these estimations are presented in table 5. The results on the managerial ownership variables are similar to the ones in table 4, the only difference being that the coefficients on the non linear specification of managerial ownership are more significant here. Our results here imply that cash holdings initially increase as managerial shareholdings increase and that they decrease and then further increase at higher levels of managerial ownership, which is in line with $\mathrm{H} 3$ and $\mathrm{H} 4$.

\section{TABLE 5}

Overall the results imply that family firms are quite heterogeneous when it comes to the role of cash holdings and that managerial ownership plays an important role in this context.

\section{Conclusion}

The aim of this paper is to investigate the determinants of cash holdings in a sample of private family firms. We find that overall the family firms in our sample hold less cash than the non-family firms. This contradicts the results of previous studies on listed firms. However, it can be argued that 
combined these results may represent the opposite ends in a continuum in which high levels of family ownership, typical to smaller private firms, lead to lower levels of cash holdings whereas low levels of family ownership, more typical to larger listed firms, lead to higher cash holdings.

Our main results indicate that ownership and control structures within the family firm also have an impact and that cash holdings are higher when there is a total separation of ownership and control in our sample of small and medium sized family firms. These results can be interpreted to imply that in cases when management holds no shares in the company, it seeks to increase its freedom to make decisions by increasing the level of cash holdings (free cash flow problem). If the level of cash holdings is high, there is less need to consult the owners or lenders of the firm. It can be further hypothesized that this supports the idea that if family firms employ outside managers, they should be required to hold equity in the firm. We also find that when ownership and control fully coincide, these firms hold less cash. When we take into account the agency costs of debt and investigate the interaction between low leverage and the fully family managed firm, we find that low leverage mitigates the impact of managerial ownership.

We also find that between the two extremes, the relationship between managerial ownership and cash holdings is nonlinear. The results further imply, that the family firms in our sample have a target cash balance and that overall cash holdings are lower in the firms which are older, and that they increase with an increase in firm age and profitability. When we separate the firms into low leverage and high leverage firms we observe that overall the firms with $100 \%$ managerial ownership hold less cash but that the low leverage firms this relationship is mitigated. 


\section{Literature}

Anderson, R. and Reeb, D., 2003, Founding-family ownership and firm performance: evidence from the S\&P 500, Journal of Finance, 58(3), 1301-28.

Arellano, M. and Bover, O., 1995, Another look at the instrumental-variable estimation of error component models, Journal of Econometrics 68 (2), 29-52.

Bennedsen, M., K. Nielsen, F. Perez-Gonzalez, and D. Wolfenzon, 2007, Inside the family firm: the role of families in succession decisions and performance, Quarterly Journal of Economics 122(2), 647-691.

Berger, A.N. and Udell, G.F., 1998, The economics of small business finance: the roles of private equity and debt markets in the financial growth cycle, Journal of Banking and Finance 22(6-8), 613-673.

Blanco-Mazagatos, V., Quevedo-Puente E. and Castrillo, L.A., 2007, The trade-off between financial resources and agency costs in the family business: an exploratory study, Family Business Review 20(3), 199-213.

Blundell, R. and Bond, S., 1998, Initial conditions and moment restrictions in dynamic panel data models, Journal of Econometrics 87, 115-143.

Chaganti, R., DeCarolis, D. and Deeds, D., 1995, Predictors of capital structure in small ventures, Entrepreneurship Theory and Practice 20(2), 7-18.

Chrisman, J.J., Chua, J.H. \& Sharma, P., 2005, Trends and directions in the development of a strategic management theory of the family firm, Entrepreneurship, Theory and Practice, 29, 555575.

Chua, J., J. Chrisman, and E. Bergiel, 2009, An agency theoretic analysis of the professionalized family firm, Entrepreneurship: Theory \& Practice, 33(2), 355-372.

Dittmar, A. and Mahrt-Smith, J., 2007, Corporate governance and the value of cash holdings, Journal of Financial Economics 83, 599-634.

Dyer, W., 2006, Examining the "family effect" on firm performance, Family Business Review 19(4), 253-73.

Fama, E.F. and Jensen, M.C., 1983, Separation of ownership and control, Journal of Law and Economics 26, 301-325.

Faulkender, M., 2002, Cash holdings among small businesses, working paper.

Fazzari, S.M., Hubbard, R.G. en Petersen, B.C., 1988, Financing constraints and corporate investment, Brookings Papers on Economic Activity 1988(1), 141-206.

Garcia-Teruel, P.J. and Martinez-Solano, P., 2008, On the determinants of SME cash holdings : evidence from Spain, Journal of Business Finance and Accounting 35(1) \& (2), 127-149.

Gedajlovic, E., Lubatkin, M.H. and Schulze, W.S. (2004). 'Crossing the treshold from founder management to professional management: a governance perspective'. Journal of Management Studies, 41(5), 899-912.

Gnan, L.. 2003, The professionalization of family firms: the role of agency cost control mechanisms, Working Paper N. 104/03, Bocconi University 1-48.

Gomez-Mejia, L., Nuñez-Nickel, M. \& Gutierrez, I., 2001, The role of family ties in agency contracts, Academy of Management Journal, 44 (1), 81-95.

Grossman, S.J. and Hart, O., 1988, One share-vote and the market for corporate control, Journal of Financial Economics 20, 175-202.

Hall, G. C., Hutchinson, P. J. and Michaelas, N., 2004, Determinants of the capital structures of European SMEs, Journal of Business Finance \& Accounting 31(5-6),711-728.

Harford, J., Mansi, S., Maxwell, W., 2008, Corporate governance and firm cash holdings in the US, Journal of Financial Economics 87, 535-555.

Hutchinson, R.W., 1995, The capital structure and investment decisions of the small ownermanaged firm: some exploratory issues, Small Business Economics 7(3), 231-239. 
Jensen, M., 1986, Agency costs of free cash flow, corporate finance and takeovers, American Economic Review 76(2), 323-329.

Kim, C.-S., Mauer, D.C. and Sherman, A.E., 1998, The determinants of corporate liquidity: theory and evidence, Journal of Financial and Quantitative Analysis 33, 335-359.

Kuan, T., Li, C., Chu S., 2010, Cash holdings and corporate governance in family-controlled firms, Journal of Business Research, forthcoming.

Lambrecht, J., and J. Lievens, 2008, Pruning the family tree: family business continuity and family harmony, Family Business Review 21(4), 295-313.

Lee, J., 2006, Family firm performance: further evidence, Family Business Review 19(2), 103-114.

López-Gracia, J. and Sánchez-Andújar, S., 2007, Financial structure of the family business: evidence from a group of small Spanish firms, Family Business Review 20(4), 269-287.

Lubatkin, M., Schulze, W., Ling, Y. \& Dino, R., 2005, The effects of parental altruism on the governance of family-managed firms, Journal of Organizational Behavior, 26, 313-30.

McMahon, R.G. and Stanger, A.M., 1995, Understanding the small enterprise financial objective function, Entrepreneurship, Theory and Practice 19(4), 21-39.

Mishra, C.S. and McConaughy, D.L., 1999, Founding family control and capital structure: the risk of loss of control and aversion to debt, Entrepreneurship, Theory and Practice, 53-64.

Niskanen, M. and Niskanen, J., 2007, Cash holdings in Finnish SME's, working paper.

Opler, T., Pinkowitz, L., Stulz, R. and Williamson, R., 1999, The determinants and implications of corporate cash holdings, Journal of Financial Economics 52, 3-46.

Ozkan, A. and Ozkan, N., 2004, Corporate cash holdings: an empirical investigation of UK companies, Journal of Banking and Finance 28, 2103-2134.

Romano, C.A., Tanewski, G.A. and Smyrnios, K.X., 2000, Capital structure decision making: a model for family business, Journal of Business Venturing 16, 285-310.

Schulze, W.S, Lubatkin, M.H., Dino, R.N. and Buchholtz, A.K., 2001, Agency relationships in family firms: theory and evidence, Organization Science 12, 99-116.

Schulze, W., Lubatkin, M. \& Dino, R.,2003, Exploring the agency consequences of ownership dispersion among the directors of private family firms, Academy of Management Journal, 46(2), 179-94.

Shanker, M. and Astrachan, J., 1996, Myths and realities: family business contribution to the US economy - a framework for assessing family business statistics, Family Business Review 9(2), 107-123.

Sonfield, M. and Lussier, R., 2004, First-, second, and third-generation family firms: a comparison, Family Business Review, 17(3), 189-202.

Steijvers, T., and W. Voordeckers, 2009, Private family ownership and the agency costs of debt, Family Business Review 22(4), 333-346.

Stiglitz, J. en Weiss, A., 1981, Credit rationing in markets with imperfect information, American Economic Review 71(3), 393-410.

Storey, D.J., 1994, Understanding the small business sector, Routledge, London.

Titman, S. and Wessels, R., 1988, The determinants of capital structure choice, Journal of Finance 43(1), 1-19.

Westhead, P. \& Howorth, C., 2007, Types of private family firms: an exploratory conceptual and empirical analysis, Entrepreneurship \& Regional Development, 19, 405-431. 


\section{Table 1}

\section{Descriptive statistics on key variables}

\begin{tabular}{lrrr}
\hline & $\mathrm{N}$ & Mean & Std. Deviation \\
\cline { 2 - 4 } & & & \\
Cash to Assets & 1177 & 0.176 & 0.184 \\
Debt to Assets & 1139 & 58.20 & 31.361 \\
Return on Assets & 485 & 16.53 & 17.57 \\
Total Assets & 1184 & 1,583 & 5,751 \\
Liquidity & 485 & 2.22 & 4.474 \\
Firm Age & 1623 & 12.91 & 12.78 \\
Managerial ownership (\%) & 1367 & 53.88 & 35.167 \\
Managerial ownership =0 & 1376 & 0.18 & 0.384 \\
Managerial ownership=100 & 1376 & 0.120 & 0.398 \\
Lenght of bank-borrower relationship & 1489 & 15.87 & 13.21 \\
& & & \\
\hline
\end{tabular}


Table 2

Descriptive Statistics on Key Variables by CEO Ownership

\begin{tabular}{|c|c|c|c|c|c|c|}
\hline \multirow[t]{3}{*}{ Panel A } & \multirow{2}{*}{\multicolumn{3}{|c|}{ Column I }} & \multirow{2}{*}{\multicolumn{3}{|c|}{ Column II }} \\
\hline & & & & & & \\
\hline & $\begin{array}{l}\text { CEO ownership } \\
=0\end{array}$ & $\begin{array}{l}\text { CEO ownership } \\
>0\end{array}$ & Significance & $\begin{array}{l}\text { CEO ownership } \\
=100\end{array}$ & $\begin{array}{l}\text { CEO } \\
\text { ownership }<100\end{array}$ & Significance \\
\hline Cash to assets & 0.171 & 0.181 & 0.489 & 0.203 & 0.174 & $0.0537^{*}$ \\
\hline Liquidity & 1.88 & 2.23 & 0.169 & 2.08 & 2.18 & 0.746 \\
\hline Debt to assets & 60.13 & 58.23 & 0.472 & 61.97 & 57.93 & 0.109 \\
\hline Total Assets & 2,626 & 499 & $0.000 * * *$ & 282 & 1,014 & $0.018 * * *$ \\
\hline ROA & 20.28 & 17.31 & 0.1456 & 21.47 & 17.18 & $0.049 * *$ \\
\hline Number of lending banks & 0.76 & 0.83 & 0.216 & 0.66 & 0.86 & $0.000 * * *$ \\
\hline Length of main bank relationship & 16.10 & 16.36 & 0.795 & 12.64 & 17.21 & $0.000 * * *$ \\
\hline Firm Age & 12.11 & 12.88 & 0.379 & 13.13 & 12.64 & 0.559 \\
\hline Low leverage & 0.507 & 0.513 & 0.823 & 0.521 & 0.506 & 0.595 \\
\hline
\end{tabular}




\begin{tabular}{|c|c|c|c|c|}
\hline \multicolumn{5}{|l|}{ Table 2 continues... } \\
\hline \multicolumn{5}{|l|}{ Panel B } \\
\hline & CEO ownership & CEO ownership & CEO ownership & CEO ownership \\
\hline & $0-5$ & $5-25$ & $25-50$ & $>50$ \\
\hline Cash to assets & 0.171 & 0.144 & 0.191 & 0.176 \\
\hline Liquidity & 1.88 & 1.15 & 2.40 & 2.40 \\
\hline Debt to assets & 60.13 & 70.19 & 56.79 & 56.85 \\
\hline Total Assets & 2,626 & 835 & 455 & 1,787 \\
\hline ROA & 20.28 & 11.05 & 16.88 & 15.83 \\
\hline Number of lending banks & 0.76 & 1.05 & 0.99 & 0.84 \\
\hline Length of main bank relationship & 16.10 & 19.76 & 15.30 & 15.60 \\
\hline Firm Age & 12.11 & 10.50 & 11.50 & 13.82 \\
\hline Low leverage & 0.52 & & & 0.52 \\
\hline
\end{tabular}


Table 3

The determinants of cash holdings in small private firms. Effect of family ownership

The dependent variable is the natural logarithm of the cash to assets ratio. Avellano-Bover/ Blundell-Bons GMM estimates

\begin{tabular}{|c|c|c|c|c|c|c|c|c|}
\hline & \multicolumn{2}{|c|}{ Column I } & \multicolumn{2}{|c|}{ Column II } & \multicolumn{2}{|c|}{ Column III } & \multirow[b]{2}{*}{ Coeff. } & \multirow[b]{2}{*}{ Prob. } \\
\hline & Coeff. & Prob. & Coeff. & Prob. & Coeff. & Prob. & & \\
\hline Constant & 2.227 & 0.148 & 1.787 & 0.249 & 3.040 & 0.067 & 1.878 & 0.251 \\
\hline \multicolumn{9}{|l|}{ Firm characeristics } \\
\hline Cash $_{\mathrm{t}-1}$ & 0.181 & 0.004 & 0.198 & 0.002 & 0.219 & 0.001 & 0.171 & 0.006 \\
\hline Ln (Total assets) & -0.348 & 0.061 & -0.320 & 0.087 & -0.343 & 0.070 & -0.263 & 0.537 \\
\hline Liquidity & 0.081 & 0.062 & 0.079 & 0.069 & 0.083 & 0.061 & -0.371 & 0.053 \\
\hline Ln(Firm age) & 0.027 & 0.811 & 0.041 & 0.711 & 0.039 & 0.727 & 0.027 & 0.805 \\
\hline Retun on assets & 0.013 & 0.000 & 0.013 & 0.000 & 0.013 & 0.000 & 0.013 & 0.000 \\
\hline Debt to assets & -0.004 & 0.262 & -0.004 & 0.272 & -0.005 & 0.239 & -0.004 & 0.237 \\
\hline \multicolumn{9}{|l|}{ Ownership } \\
\hline Family Ownership \% & -0.021 & 0.024 & & & & & & \\
\hline Family Firm Dummy & & & -1.300 & 0.079 & -2.963 & 0.006 & -2.244 & 0.052 \\
\hline Management holds $0 \%$ & & & & & 0.096 & 0.882 & & \\
\hline Management holds $100 \%$ & & & & & & & -0.534 & 0.743 \\
\hline Family Firm x Mgt holds $0 \%$ & & & & & 0.022 & 0.084 & & \\
\hline Family Firm x Mgt holds $100 \%$ & & & & & & & 2.038 & 0.212 \\
\hline Banking relationship length & -0.509 & 0.179 & -0.530 & 0.172 & -0.680 & 0.082 & -0.263 & 0.537 \\
\hline Wald Chi2 & 54.99 & 0.000 & 51.93 & 0.000 & 57.15 & 0.000 & 56.27 & 0.000 \\
\hline Number of observations & 628 & & 628 & & 628 & & 628 & \\
\hline
\end{tabular}




\section{Table 4}

\section{The determinants of cash holdings in family firms. Effect of managerial ownership}

The dependent variable is the natural logarithm of the cash to assets ratio. Avellano-Bover/ Blundell-Bons GMM estimates.

\begin{tabular}{|c|c|c|c|c|c|c|c|c|c|c|}
\hline & \multicolumn{2}{|c|}{ Column I } & \multicolumn{2}{|c|}{ Column II } & \multicolumn{2}{|c|}{ Column III } & \multicolumn{2}{|c|}{ Column IV } & \multicolumn{2}{|c|}{ Column V } \\
\hline & Coeff. & Prob. & Coeff. & Prob. & Coeff & Prob. & Coeff. & Prob. & Coeff. & Prob. \\
\hline Constant & 3.441 & 0.146 & 0.767 & 0.606 & 0.030 & 0.985 & 0.751 & 0.601 & 1.499 & 0.329 \\
\hline \multicolumn{11}{|l|}{ Firm characeristics } \\
\hline Cash $_{\mathrm{t}-1}$ & 0.074 & 0.443 & 0.095 & 0.316 & -0.013 & 0.876 & 0.074 & 0.411 & -0.006 & 0.938 \\
\hline Ln (Total assets) & -0.753 & 0.024 & -0.840 & 0.001 & -0.629 & 0.015 & -0.863 & 0.001 & -0.814 & 0.001 \\
\hline Liquidity & 0.116 & 0.045 & 0.125 & 0.031 & 0.111 & 0.054 & 0.101 & 0.067 & 0.088 & 0.094 \\
\hline Ln(Firm age) & 0.165 & 0.342 & 0.197 & 0.249 & 0.163 & 0.335 & 0.156 & 0.351 & 0.075 & 0.637 \\
\hline Retun on assets & 0.022 & 0.000 & 0.024 & 0.000 & 0.022 & 0.000 & 0.021 & 0.000 & 0.018 & 0.001 \\
\hline Debt to assets & -0.0001 & 0.983 & 0.0001 & 0.984 & 0.0001 & 0.994 & & & & \\
\hline Low leverage (dummy) & & & & & & & 0.666 & 0.030 & 0.080 & 0.801 \\
\hline \multicolumn{11}{|l|}{ Ownership } \\
\hline Managerial ownership & -0.0003 & 0.968 & & & & & & & & \\
\hline Managerial ownership 2 & -0.002 & 0.006 & & & & & & & & \\
\hline Managerial ownership 3 & 0.0001 & 0.019 & & & & & & & & \\
\hline Management holds $0 \%$ & & & 4.194 & 0.000 & & & 4.036 & 0.000 & & \\
\hline Management holds $100 \%$ & & & & & 0.379 & 0.702 & & & -1.737 & 0.076 \\
\hline Low leverage x Mgt holds $0 \%$ & & & & & & & -0.977 & 0.387 & & \\
\hline Low leverage x Mgt holds $100 \%$ & & & & & & & & & 2.694 & 0.000 \\
\hline Relationship length & 0.237 & 0.497 & -0.065 & 0.847 & -0.020 & 0.955 & -0.234 & 0.943 & -0.008 & 0.981 \\
\hline Wald Chi2 & 41.31 & 0.000 & 42.03 & 0.000 & 29.72 & 0.000 & 48.53 & 0.000 & 53.00 & 0.000 \\
\hline Number of observations & 270 & & 270 & & 270 & & 270 & & 270 & \\
\hline
\end{tabular}




\section{Table 5}

\section{The determinants of cash holdings in family firms. Effect of managerial ownership}

The dependent variable is the natural logarithm of the cash to assets ratio. Random Effects GLS estimates.

\begin{tabular}{|c|c|c|c|c|c|c|c|c|c|c|}
\hline & \multicolumn{2}{|c|}{ Column I } & \multicolumn{2}{|c|}{ Column II } & \multicolumn{4}{|c|}{ Column III } & \multirow[b]{2}{*}{ Coeff. } & \multirow[b]{2}{*}{ Prob. } \\
\hline & Coeff. & Prob. & Coeff. & Prob. & Coeff & Prob. & Coeff. & Prob. & & \\
\hline Constant & 0.559 & 0.438 & 0.454 & 0.771 & 0.254 & 0.881 & -0.383 & 0.562 & 0.150 & 0.825 \\
\hline \multicolumn{11}{|l|}{ Firm characeristics } \\
\hline Ln (Total assets) & -0.505 & 0.000 & -0.461 & 0.000 & -0.424 & 0.000 & -0.432 & 0.000 & -0.435 & 0.000 \\
\hline Liquidity & 0.131 & 0.001 & 0.121 & 0.002 & 0.121 & 0.002 & 0.128 & 0.001 & 0.126 & 0.001 \\
\hline Ln(Firm age) & -0.031 & 0.712 & -0.059 & 0.483 & -0.067 & 0.430 & -0.072 & 0.396 & 0.069 & 0.408 \\
\hline Retun on assets & 0.016 & 0.000 & 0.015 & 0.000 & 0.016 & 0.000 & 0.017 & 0.000 & 0.016 & 0.000 \\
\hline Debt to assets & -0.008 & 0.014 & -0.007 & 0.018 & -0.007 & 0.021 & & & & \\
\hline Low leverage (dummy) & & & & & & & 0.511 & 0.012 & 0.259 & 0.214 \\
\hline \multicolumn{11}{|l|}{ Ownership } \\
\hline Managerial ownership & 0.006 & 0.035 & & & & & & & & \\
\hline Managerial ownership ${ }^{2}$ & -0.001 & 0.017 & & & & & & & & \\
\hline Managerial ownership ${ }^{3}$ & 0.0001 & 0.034 & & & & & & & & \\
\hline Management holds $0 \%$ & & & 0.621 & 0.036 & & & 0.689 & 0.042 & & \\
\hline Management holds $100 \%$ & & & & & -0.001 & 0.996 & & & -0.957 & 0.011 \\
\hline Low leverage $\mathrm{x}$ Mgt holds $0 \%$ & & & & & & & -0.227 & 0.654 & & \\
\hline Low leverage x Mgt holds $100 \%$ & & & & & & & & & 1.232 & 0.004 \\
\hline Relationship length & -0.143 & 0.360 & -0.175 & 0.271 & -0.237 & 0.124 & -0.175 & 0.273 & -0.258 & 0.096 \\
\hline Wald Chi2 & 87.21 & 0.000 & 79.85 & 0.000 & 76.97 & 0.000 & 80.14 & 0.000 & 86.26 & 0.000 \\
\hline Number of observations & 348 & & 348 & & 348 & & 348 & & 348 & \\
\hline
\end{tabular}

